DOI: 10.17707/AgricultForest.64.4.25

Senad MURTIĆ, Ćerima ZAHIROVIĆ,
Hamdija ČIVIĆ, Lutvija KARIĆ, Josip JURKOVIĆ ${ }^{1}$

\title{
UPTAKE OF HEAVY METALS BY TOMATO PLANTS (Lycopersicum esculentum Mill.) AND THEIR DISTRIBUTION INSIDE THE PLANT
}

\begin{abstract}
SUMMARY
The aim of this study was to examine the concentration of total and available forms of heavy metals (Ni, Cr, $\mathrm{Cu}, \mathrm{Zn}, \mathrm{Pb}$ and $\mathrm{Mn}$ ) in the greenhouse soils as well as the distribution of these metals in the different parts of tomato plants grown on these soils. Atomic Absorption Spectroscopy (AAS) was used to determine heavy metals concentration. The concentration of available forms of all examined heavy metals in the soils and in tomato fruits were low, although the total concentration of hazardous heavy metals $\mathrm{Ni}$ and $\mathrm{Cr}$ in soils exceeded the maximum permissible values, prescribed by legislative rules in Bosnia and Herzegovina.

The reasons for the low uptake of heavy metals by tomato plants are mainly related to the chemical properties of soil which are not favorable for heavy metal availability. In addition, the results of this study also showed that the accumulation of all examined heavy metals especially $\mathrm{Cr}$ and $\mathrm{Ni}$ were much higher in the roots than in the fruits. The low accumulation of heavy metals in tomato fruits is the result of synergy of different plant defense mechanisms that limiting or reducing heavy metal transport from root to fruits.
\end{abstract}

Key words: transport, root, leaves, fruit, greenhouse soil

\section{INTRODUCTION}

The intensification of agricultural soil use, and changes in farming practice, characterized by intensive application of fertilizers and pesticides may cause soil pollution by heavy metals in greenhouses (Nouri et al., 2008). Namely, many chemical products used in agriculture, especially nitrogen and phosphate fertilizers, contain certain amounts of heavy

\footnotetext{
${ }^{1}$ Senad Murtić (corresponding author: murticsenad@hotmail.com), Ćerima Zahirović, Hamdija Čivić, Lutvija Karić, Josip Jurković, University of Sarajevo, Faculty of Agriculture and Food Sciences, Department of Plant Physiology, Sarajevo, BOSNIA AND HERZEGOVINA

Notes: The authors declare that they have no conflicts of interest. Authorship Form signed online.
} 
metals, as result of their production from minerals used as a source of these elements.

Although the low level of heavy metals in fertilizers and pesticides in one-time use do not pose any hazard of soil or plant contamination, their long-term use in food crops production, especially in greenhouse vegetable production, contributed to the accumulation of heavy metals in the soils and consequently in food crops (Huang and Jin, 2008).

Cadmium (Cd), chromium (Cr) and lead $(\mathrm{Pb})$ are the heavy metals of most concern because they can affect human health even in small quantities. $\mathrm{Wa}^{\circ}$ ngstrand et al. (2007) reported that application of nitrogen fertilizers containing ammonium- $\mathrm{N}$ may increase $\mathrm{Cd}$ concentrations in plants, even if the fertilizers do not contain significant levels of heavy metals. In addition, Atafar et al. (2010) were also observed that application of some non-heavy metal fertilizers can potentially increase concentrations of $\mathrm{Cd}, \mathrm{Cr}$, and $\mathrm{Pb}$ in plants.

The conclusion of their work was that the application of acidic fertilizers in soils dramatically decreases soil $\mathrm{pH}$ resulting in desorption of heavy metals from the soil matrix and their higher bioavailability by plants.

Accordingly, determining the available forms of heavy metals in soils is an important approach to the soil contamination assessment, especially in greenhouse areas which have great impact on environment and human health due to intensive use of fertilizers and pesticides containing heavy metals.

However, up to now, heavy metal concentrations of greenhouse soil in Bosnia and Herzegovina and its pollution problem have been studied very little, especially there is no systematical investigation of the dynamics of heavy metals in the greenhouse soil-plant system in intensive tomato production. Since the heavy metals have a long residence time in soils, it is very important to study the status of heavy metals in soil, and their influence on vegetable safety, and consequently human health.

The objective of this study was to examine the concentration of total and available forms of heavy metals ( $\mathrm{Ni}, \mathrm{Cr}, \mathrm{Cu}, \mathrm{Zn}, \mathrm{Pb}$ and $\mathrm{Mn}$ ) in the greenhouse soils as well as the distribution of heavy metals in the different parts of tomato plants (Lycopersicum esculentum Mill. 'Berberana F1') grown on these soils. Tomato was selected as the subject of this study, primarily because the global production of this vegetable is consistently increasing in our country and therefore, any attempt to evaluate the health risks of consumption of tomato or other vegetable crops grown on greenhouse soils is of great interest to producers and consumers. 


\section{Study area}

\section{MATERIAL AND METHODS}

The experiment was carried out from March to July 2018 in a multi-span plastic greenhouse with natural ventilation at Srebrenik, north eastern part of Bosnia and Herzegovina. The geometrical characteristics of the greenhouse were as follows: eaves height of $2.2 \mathrm{~m}$; ridge height of 3.6 $\mathrm{m}$; total width of $8 \mathrm{~m}$; total length of $20 \mathrm{~m}$; ground area of $160 \mathrm{~m}^{2}$, and total volume of $480 \mathrm{~m}^{3}$. The greenhouse was polyethylene covered and equipped with two side roll-up vents. Shade cloth was used to prevent excessive light intensity during warm day.

Fertilizer application in greenhouse studied area was based on use of different chemical fertilizers: slow release NPK (nitrogen-phosphoruspotassium) compound fertilizers applied before vegetable growth, and quick release fertilizers (urea, potassium fertilizers, foliar fertilizers) applied during intensive vegetable growth and development. Average amount of applied chemical fertilizers was approximately $1000 \mathrm{~kg} \mathrm{ha}^{-1}$ year $^{-1}$. Application of fertilizers on the studied greenhouse area was managed in this way for eight years from the time of establishment.

According to FAO Soil Classification (FAO, 1998), the soil on which the greenhouse is placed belongs to eutric cambisol. Pedological profile A - Bv - C and base saturation degree higher than 50\%, at least in the upper part of the Bv horizon, is a typical characteristic of this type of soil. Furthermore, eutric cambisols have relatively good structure and chemical properties, and therefore moderate sensitivity to yield decline (Husnjak, 2014).

\section{Soil sampling}

Experimental ground area in greenhouse was divided into three equal plots. The soil sample from every plot were collected in March 2018, few weeks before tomatoes planting, at a depth of $0-30 \mathrm{~cm}$ using stainless steel shovel. Each plot sample was obtained from five individual soil cores that were thoroughly mixed to make one sample. These three plot samples were mixed to form the average greenhouse soil sample.

\section{Soil analysis}

The soil samples were air-dried at room temperature, and then crushed and grinded using soil porcelain mortar and pestle to achieve homogeneity. After, samples were passed through sieves (2 and $1 \mathrm{~mm}$ ) and then stored until analysis.

Following parameters were subject of soil chemical analysis: soil reaction $(\mathrm{pH})$, soil organic matter, available forms of phosphorus and potassium, and concentration of total and available forms of heavy metals (Ni, Cr, $\mathrm{Cu}, \mathrm{Zn}, \mathrm{Pb}$ and $\mathrm{Mn}$ ). 
Soil reaction $(\mathrm{pH})$ in $\mathrm{H}_{2} \mathrm{O}$ and $1 \mathrm{~mol} \mathrm{dm^{3 }} \mathrm{KCl}$ was determined according to ISO 10390 method (ISO, 2005), organic matter (OM) according to ISO 14235 method (ISO, 1998), available forms of phosphorus and potassium by ammonium-lactate extraction (Egner et al., 1960), and total and available forms of heavy metals by atomic absorption spectrophotometer (AA-7000, Shimadzu, Japan) according to the instructions specified in the ISO 11047 method (ISO, 1998). Measurements were made in triplicate to check the precision of the results.

Previous extraction of total $\mathrm{Ni}, \mathrm{Cr}, \mathrm{Cu}, \mathrm{Zn}, \mathrm{Pb}$ and $\mathrm{Mn}$ from the soil was conducted using aqua regia solution (ISO, 1995) as follows: 3 grams of air-dried soil (fraction smaller than $1 \mathrm{~mm}$ ) was placed in $250 \mathrm{ml}$ flat bottom flask, then $28 \mathrm{ml}$ of aqua regia was added $(21 \mathrm{ml} \mathrm{HCl}$ and 7 $\mathrm{ml} \mathrm{HNO}_{3}$ ). The flask was covered with a watch glass, allowed to stand 16 $\mathrm{h}$ (overnight) at room temperature, and then was heated on hotplate under reflux for $2 \mathrm{~h}$. After cooling down to room temperature, solution was filtered through quantitative filter paper into $100 \mathrm{ml}$ flask and diluted to the mark with deionized water.

Extraction of available forms of heavy metals from the soil was performed using EDTA solution (Trierweiler and Lindsay, 1969) as follows: $10 \mathrm{~g}$ of air-dried soil was placed into $100 \mathrm{ml}$ plastic bottle, then

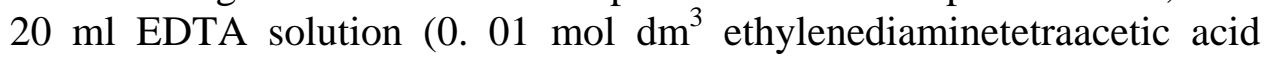
(EDTA) and $1 \mathrm{M}\left(\mathrm{NH}_{4}\right)_{2} \mathrm{CO}_{3}$, adjusted to $\mathrm{pH}$ 8.6) was added. The bottle has been shaken $30 \mathrm{~min}$ at $180 \mathrm{rpm}$ in an orbital shaker, then extract was filtered through quantitative filter paper into $25 \mathrm{ml}$ flask and diluted to the mark with deionized water.

\section{Plant sampling}

Five tomato plants (whole plant with root) from each examined plot were carefully collected at the stage of commercial maturity. Leaves, root, and fruits of every plants were separated, dried at room temperature, grinded and then stored in little paper bags until analyses.

\section{Plant analysis}

The concentration of heavy metals ( $\mathrm{Ni}, \mathrm{Cr}, \mathrm{Cu}, \mathrm{Zn}, \mathrm{Pb}$ and $\mathrm{Mn}$ ) in the plant samples was also determined by atomic absorption spectrophotometer (AA-7000, Shimadzu, Japan) according to ISO 11047 method. Measurements were made in triplicate for each plant sample to check the precision of the results.

Previous extraction of heavy metals from the plant material was performed using $\mathrm{HNO}_{3}-\mathrm{H}_{2} \mathrm{SO}_{4}$ solution (Lisjak et al., 2009) as follows: 1 $\mathrm{g}$ of dry matter was placed in $100 \mathrm{ml}$ flat bottom flask, and $10 \mathrm{ml} \mathrm{HNO}_{3}$ and $4 \mathrm{ml} \mathrm{H}_{2} \mathrm{SO}_{4}$ were added. The flask was covered with a watch glass, allowed to stand for few hours at room temperature and then heated gently 
on a hot plate for thirty minutes. After cooling down to room temperature, the extract was filtered through quantitative filter paper into $50 \mathrm{ml}$ flask and diluted with deionized water to the mark.

\section{Statistical analysis}

All results were presented as mean \pm standard deviation and were processed by one-way analysis of variance (ANOVA). The differences between means were tested using the least significance difference (LSD) test at $\mathrm{P}<0.05$.

\section{RESULTS}

\section{Chemical properties of the greenhouse soil}

The analysis of basic parameters of soil fertility showed that the examined soil had a slightly acid reaction, moderate level of organic matter (OM), and high content of available forms of phosphorus $\left(\mathrm{P}_{2} \mathrm{O}_{5}\right)$ and potassium $\left(\mathrm{K}_{2} \mathrm{O}\right)$, indicating that the examined greenhouse soil is suitable for tomato cultivation (Table 1 ).

Table 1. Results of soil chemical analysis

\begin{tabular}{|cccc|}
\hline Parameter & unit & $\begin{array}{c}\text { measured } \\
\text { value }\end{array}$ & $\begin{array}{c}\text { recommended values } \\
\text { for vegetable } \\
\text { production }\end{array}$ \\
\hline $\mathrm{pH} \mathrm{H}{ }_{2} \mathrm{O}$ & $\mathrm{pH}$ unit & 6.9 & $5.7-7.2$ \\
\hline $\mathrm{pH} \mathrm{KCl}$ & $\mathrm{pH} \mathrm{unit}$ & 6.1 & $5.2-6.7$ \\
\hline $\mathrm{OM}$ & $\%$ & 3.83 & $3-5$ \\
\hline $\mathrm{P}_{2} \mathrm{O}_{5}$ & $\mathrm{mg} \mathrm{100} \mathrm{g}^{-1}$ & 43.06 & $12-16$ \\
\hline $\mathrm{K}_{2} \mathrm{O}$ & $\mathrm{mg} \mathrm{100} \mathrm{g}^{-1}$ & 110 & $25-35$ \\
\hline
\end{tabular}

*values reported by Vukadinovic and Vukadinovic (2011)

\section{Heavy metal concentrations in soil}

Total and available heavy metals concentration $(\mathrm{Ni}, \mathrm{Cr}, \mathrm{Cu}, \mathrm{Zn}, \mathrm{Pb}$, $\mathrm{Mn}$ ) in the average greenhouse soil sample are listed in Table 2.

Table 2. The heavy metal concentrations in the average soil sample

\begin{tabular}{|c|c|c|c|c|c|c|}
\hline \multirow[b]{2}{*}{ greenhouse soil } & \multicolumn{6}{|c|}{ Concentration (mg kg ${ }^{-1}$ dry mass) } \\
\hline & $\mathrm{Ni}$ & $\mathrm{Cr}$ & $\mathrm{Cu}$ & $\mathrm{Zn}$ & $\mathrm{Pb}$ & Mn \\
\hline total & 216.58 & 127.56 & 22.57 & 38.39 & 15.4 & 256.18 \\
\hline limit value & $40^{*}$ & $100^{*}$ & $80^{*}$ & $100^{*}$ & $100^{*}$ & $850^{* *}$ \\
\hline available forms & 3.99 & 0.13 & 2.23 & 1.54 & 0.46 & 6.33 \\
\hline
\end{tabular}

${ }^{*}$ limit value prescribed by B \& H legislation;

${ }^{* *}$ toxic level of Mn in soils reported by Pais and Jones (1997) 
The highest total concentration was recorded for Mn, followed by $\mathrm{Ni}, \mathrm{Cr}, \mathrm{Zn}, \mathrm{Cu}$, and $\mathrm{Pb}$ content being the lowest one. The concentration of heavy metal $\mathrm{Ni}$ and $\mathrm{Cr}$ exceeds the limit value in soils prescribed by the legislation in Bosnia and Herzegovina (Official Gazette of FBIH, 2009), while the concentration of $\mathrm{Zn}, \mathrm{Cu}$ and $\mathrm{Pb}$ did not exceed the limit value prescribed by the same legislation.

Limit value of $\mathrm{Mn}$ in soils is not in the legislative rules, because $\mathrm{Mn}$ is not direct contaminant of soil. However, the concentration of $\mathrm{Mn}$ in examined soil did not exceed the toxic level of $\mathrm{Mn}$ in soils (850 $\mathrm{mg} \mathrm{kg}^{-1}$ ) reported by Pais and Jones (1997).

\section{Heavy metal concentrations in tomato plants}

Heavy metals concentration ( $\mathrm{Ni}, \mathrm{Cr}, \mathrm{Cu}, \mathrm{Zn}, \mathrm{Pb}, \mathrm{Mn}$ ) in different parts of tomato plants are presented in Table 3.

Table 3. Concentration of heavy metals in tomato plants

\begin{tabular}{|c|c|c|c|c|c|c|}
\hline \multirow{2}{*}{$\begin{array}{l}\text { Part } \\
\text { of the } \\
\text { plant }\end{array}$} & \multicolumn{6}{|c|}{ Concentration (mg kg ${ }^{-1}$ dry mass) } \\
\hline & $\mathrm{Ni}$ & $\mathrm{Cr}$ & $\mathrm{Cu}$ & $\mathrm{Zn}$ & $\mathrm{Pb}$ & $\mathrm{Mn}$ \\
\hline root & $32.4 \pm 3.00$ & $\underset{\mathrm{a}}{12.92 \pm 5.27}$ & $10.24 \underset{\mathrm{a}}{ \pm} 0.79$ & $\underset{\mathrm{a}}{30.95 \pm 3.03}$ & n.d & $94.35 \pm 29.9$ \\
\hline stem & $2.81 \pm 0.13$ & $0.97 \pm 0.04^{b}$ & $1.85 \pm 0.51^{\mathrm{C}}$ & $\underset{\mathrm{c}}{14.23 \pm 1.92}$ & n.d & $9.59 \pm 1.17^{\mathrm{c}}$ \\
\hline leaves & $3.23 \pm 0.29$ & $1.02 \pm 0.13^{b}$ & $2.65 \pm 0.39^{c}$ & $14.72 \pm 0.36$ & n.d & $43.83 \pm 1.71$ \\
\hline fruit & $2.16 \frac{ \pm 0.11}{b}$ & $1.11 \pm 0.22^{b}$ & $4.83 \pm 1.66^{b}$ & $19.51 \pm 1.44$ & n.d & $10.05 \pm 5.11$ \\
\hline $\begin{array}{l}\operatorname{Lsd}_{0.0} \\
5\end{array}$ & 1.23 & 2.21 & 0.85 & 1.64 & - & 12.13 \\
\hline
\end{tabular}

significant; n.d. - not determined

Presented data have shown that the concentration of all tested heavy metals in tomato fruits was below the maximum permissible value of heavy metals in food crops reported by FAO/WHO (2001). Accordingly, the maximum permissible value for $\mathrm{Ni}$ is $4 \mathrm{mg} \mathrm{kg}^{-1}$, for $\mathrm{Cr}$ $2.3 \mathrm{mg} \mathrm{kg}^{-1}$, for $\mathrm{Cu} 40 \mathrm{mg} \mathrm{kg}^{-1}$. for $\mathrm{Zn} 100 \mathrm{mg} \mathrm{kg}^{-1}$, and for $\mathrm{Pb} 0.3 \mathrm{mg}$ $\mathrm{kg}^{-1}$. The maximum permissible value for $\mathrm{Mn}$ is not reported by FAO/WHO since the Mn is not considered a health hazard. 


\section{DISCUSSION}

Contamination of greenhouse soils by heavy metals as a result of long-term use of fertilizers and pesticides in food crops production becomes more and more intense, resulting in harmful effects on human health through consumption of food crops grown on these soils (Liu et al., 2014). Thus, it is imperative to reduce heavy metal contamination in greenhouse soils, and in order to achieve this goal, legislation of some developed countries has set tolerance limits on heavy-metal additions (fertilizers and biosolids) to soils. Unfortunately, Bosnia and Herzegovina (B \& $\mathrm{H}$ ) has no legislative rules associated with this issue. In our country only maximum permissible concentrations of hazardous heavy metals $(\mathrm{Cr}$, $\mathrm{Cd}, \mathrm{Pb}, \mathrm{Ni}, \mathrm{Cu}, \mathrm{Zn}$ ) in agricultural soils were prescribed by legislation. If the concentration of any of the above-mentioned heavy metals in the soil is higher than limit value, such soil can be considered as polluted by heavy metals and not suitable for agriculture.

In this study, it was determined that the total concentration of $\mathrm{Ni}$ and $\mathrm{Cr}$ exceeded the maximum permissible value for agricultural soil prescribed by legislation in B \& H. These results lead to the conclusion that the examined soil is polluted by $\mathrm{Ni}$ and $\mathrm{Cr}$. Nevertheless, the available forms of these elements in the same soil were very low. Moreover, the amount of available $\mathrm{Cr}$ in examined soil was less than $0.1 \%$ of total $\mathrm{Cr}$ concentration in soil, and from these results it is evident that the total concentration does not provide reliable information on the mobility, availability and toxicity of the heavy metals, especially Ni and Cr. Many scientists agree with our observation that the total amounts of heavy metals in soils are not suitable for estimating the solubility and mobility and consequently the toxicity of heavy metals (Abollino et al., 2002; Pueyo et al., 2004; Nunes et al., 2014). The results of heavy metals analysis in tomato fruits also confirm that observation. Namely, the average $\mathrm{Cr}$ and $\mathrm{Ni}$ concentration in tomato fruits was 1.11 and $2.16 \mathrm{mg} \mathrm{kg}$ 1 respectively, which is significantly lower in comparison with the maximum permissible value of $\mathrm{Cr}\left(2.3 \mathrm{mg} \mathrm{kg}^{-1}\right)$ and $\mathrm{Ni}\left(4 \mathrm{mg} \mathrm{kg}^{-1}\right)$ in food crops reported by FAO/WHO (2001).

One of the main reasons for the low mobility of $\mathrm{Ni}$ and $\mathrm{Cr}$ in examined soils and consequently for their relatively low accumulation in tomato fruits are closely related to the chemical properties of soils, primarily to soil reaction (Nadgórska-Socha et al., 2013). Our examined greenhouse soil had a slightly acid reaction, which is not the most favorable for the mobility and availability of $\mathrm{Cr}$ and $\mathrm{Ni}$ to plant roots. Mobility and availability of these elements is much higher in strongly 
acidic soils, and results of many studies confirm that fact (Kukier et al., 2004; Adamczyk-Szabela et al., 2015).

The total concentration of other tested heavy metals $(\mathrm{Cu}, \mathrm{Zn}, \mathrm{Pb}$, $\mathrm{Mn}$ ) in examined soils did not exceed the maximum permissible value for agricultural soil prescribed by $\mathrm{B} \& \mathrm{H}$ legislation, indicating that investigate soil is not polluted with these heavy metals. The concentration of these elements in tomato fruits were also lower than the maximum permissible value of heavy metals in food crops reported by FAO/WHO (2001). Moreover, the presence of $\mathrm{Pb}$ was not determined in any parts of tomato plants. This data is highly desirable, since the $\mathrm{Pb}$ is extremely harmful to human health through consumption of food crops even in small quantities.

The results of this study also showed that all the examined heavy metals especially $\mathrm{Cr}$ and $\mathrm{Ni}$ accumulated in higher amounts in the roots than in the above-ground parts of a plant. These results agree with results of other authors who examined this issue (Adki et al., 2013; Wu et al., 2013).

Gomes et al. (2017) reported that plants possess several different strategies to neutralize the negative impact of heavy metals on plants. One of first strategies is related to limit their uptake from the soil through complexing metals with organic compounds produced and exuded from the roots. If hazardous heavy metal enters the root, plants may activate different tolerance mechanisms such as metal compartmentalization in different intracellular compartments, or biosynthesis and accumulation of several compounds aimed at metal complexation, thus prevention of their transport from root to other part of plants. Selection of strategy primarily depends of plant genetic background and growth conditions. The results of this study related to the availability of heavy metals in soils and their accumulation in the plant strongly support above-mentioned hypotheses.

Interesting finding of this study was that the concentrations of hazardous heavy metal $\mathrm{Cr}$ and $\mathrm{Ni}$ were even 10 to 15-fold higher in the root than in other parts of tomato plants, while the difference in distribution within the plant was much lower for $\mathrm{Mn}, \mathrm{Zn}$ and $\mathrm{Cu}$. Taking into account that these elements $(\mathrm{Mn}, \mathrm{Zn}$ and $\mathrm{Cu}$ ) are necessary for plant metabolism, mainly in photosynthesis and as an enzyme antioxidantcofactor (Nguyen-Deroche et al., 2012; Farzadfar et al., 2017), the results of this part of study lead to the conclusion that mechanisms for reducing or preventing transport of these elements from root to other parts of tomato plants are not fully activated.

On the other hand, for highly hazardous heavy metals such as $\mathrm{Cd}$, $\mathrm{Cr}$, and $\mathrm{Pb}$, these mechanisms are significantly more involved in the 
tomato plant's defense system. It is certain that the plants have developed many types of mechanisms for identifying and involving heavy metals into their metabolism, but also for blocking them if their presence is harmful to the plant. Understanding these mechanisms creates a predisposition to write correct conclusions about the possibilities of tomato cultivation on soils contaminated by heavy metals.

\section{CONCLUSION}

The general conclusions of this study were that the reaction of examined greenhouse soil was not favorable for the mobility and availability of heavy metals by plants, contributing to the lower accumulation of heavy metals in the plant. Furthermore, tomato plants accumulated heavy metals mainly in root, indicating that these plants possess different heavy metals tolerance mechanisms to limit or reduce the accumulation of hazardous heavy metals in fruits.

\section{REFERENCES}

Abollino, O., Aceto, M., Malandrino, M., Mentasti, E., Sarzanini, C., \& Petrella, F. (2002). Heavy metals in agricultural soils from Piedmont, Italy. Distribution, speciation and chemometric data treatment. Chemosphere, 49(6), 545-557.

Adamczyk-Szabela, D., Markiewicz, J., \& Wolf, W. M. (2015). Heavy metal uptake by herbs. IV. Influence of soil $\mathrm{pH}$ on the content of heavy metals in Valeriana officinalis L. Water, Air, \& Soil Pollution, 226, 106.

Adki, V. S., Jadhav, J. P., \& Bapat, V. A. (2013). Nopalea cochenillifera, a potential chromium (VI) hyperaccumulator plant. Environmental Science and Pollution Research, 20, 1173-1180.

Atafar, Z., Mesdaghinia, A., Nouri, J., Homaee, M., Yunesian, M., Ahmadimoghaddam, M., \& Mahvi, A. H. (2008). Effect of fertilizer application on soil heavy metal concentration. Environmental Monitoring and Assessment, 160, 83-89.

Egnér, H., Riehm, H., \& Domingo, W. R. (1960). Untersuchungen über die chemische Boden analyse als Grundlage für die Beurteilung de Nährstoffzustandes der Böden. II. Chemische Extraktions methoden zur Phosphor - und Kaliumbestimmung. Kungliga Lantbrukshögskolans Annaler, 26, 199-215.

FAO (1998). World Reference Base for Soil Resources. Food and Agriculture Organization of the United Nations, Rome, Italy. World Soil Resources Report No. 84 (also available at www.fao.org).

FAO/WHO (2001). Report on the 32nd Session of the Codex Committee on Food Additives and Contaminants, ALINORM 01/12, Beijing, China, 20-24 March 2000. Joint FAO/WHO Food Standard Programme, Codex Alimentarius Commission, 24th Session, 2-7 July, Geneva, Switzerland (also available at www.fao.org).

Farzadfar, S., Zarinkamar, F., \& Hojati, M. (2017). Magnesium and manganese affect photosynthesis, essential oil composition and phenolic compounds of Tanacetum parthenium. Plant Physiology and Biochemistry, 112, 207-217. 
Gomes, M. A., Hauser-Davis, R. A., Suzuki, M. S., \& Vitória, A. P. (2017). Plant chromium uptake and transport, physiological effects and recent advances in molecular investigations. Ecotoxicology and Environmental Safety,140, 55-64.

Huang, S. W., \& Jin, J. Y. (2008). Status of heavy metals in agricultural soils as affected by different patterns of land use. Environmental Monitoring and Assessment, 139, 317-327.

Husnjak, S. (2014). Sistematika tala Hrvatske. Zagreb, Croatia, Hrvatska sveučilišna naklada.

ISO (1995). International Standard ISO 11466, Soil quality - Extraction of trace elements soluble in aqua regia, International Organization for Standardization, Geneva, Switzerland (also available at www.iso.org).

ISO (1998). International Standard ISO 11047, Soil quality - Determination of cadmium, chromium, cobalt, copper, lead, manganese, nickel and zinc - Flame and electrothermal atomic absorption spectrometric methods, International Organization for Standardization, Geneva, Switzerland (also available at www.iso.org).

ISO (1998). International Standard ISO 14235, Soil quality - Determination of organic carbon in soil by sulfochromic oxidation, International Organization for Standardization, Geneva, Switzerland (also available at www.iso.org).

ISO (2005). International Standard ISO 10390, Soil quality - Determination of pH. International Organization for Standardization, Geneva, Switzerland (also available at www.iso.org).

Kukier, U., Peters, C. A., Chaney, R. L., Angle, J. S., \& Roseberg, R. J. (2004). The effect of $\mathrm{pH}$ on metal accumulation in two Alyssum species. Journal of Environmental Quality, 33(6), 2090-2102.

Lisjak, M., Špoljarević, M., Agić, D., \& Andrić, L. (2009). Praktikum iz fiziologije bilja. Osijek, Hrvatska, Poljoprivredni fakultet u Osijeku.

Liu, L., Lu, J. Y., Zhang, Z. W., Zheng, H., Gao, X. Q., \& Zhang, W. (2014). Heavy Metals Contamination in Greenhouse Soils and Vegetables in Guanzhong, China. Journal of Engineering and Applied Sciences, 4(3), 80-88.

Nadgórska-Socha, A., Kafel, A., Kandziora-Ciupa, M., Gospodarek, J., \& ZawiszaRaszka, A. (2013). Accumulation of heavy metals and antioxidant responses in Vicia faba plants grown on monometallic contaminated soil. Environmental Science and Pollution Research, 20(2), 1124-1134.

Nguyen-Deroche, T. L. N., Caruso, A., Le, T. T., Bui, T. V., Schoefs, B., Tremblin, G., \& Morant-Manceau, A. (2012). Zinc affects differently growth, photosynthesis, antioxidant enzyme activities and phytochelatin synthase expression of four marine diatoms. Science World Journal, 2012, 982957.

Nouri, J., Mahvi, A. H., Jahed, G. R., \& Babaei, A. (2008). A regional distribution pattern of groundwater heavy metals resulting from agricultural activities. Environmental Geology, 55, 1337-1343.

Nunes, J. R., Ramos-Miras, J., Lopez-Piñeiro, A., Loures, L., Gil, C., Coelho, J., \& Loures, A. (2014). Concentrations of available heavy metals in Mediterranean agricultural soils and their relation with some soil selected properties: A case study in typical Mediterranean soils. Sustainability, 6, 9124-9138.

Official Gazette of FBiH (2009). Rulebook on determination of allowable quantities of harmful and hazardous substances in soils of Federation of Bosnia and Herzegovina and methods for their testing, No 72/09. Sarajevo, Bosnia and Herzegovina. 
Pais, I., \& Jones, J. B. (1997). The Handbook of Trace Elements. Boca Raton, Lucie Press.

Pueyo, M., Lopez-Sanchez, J. F., \& Rauret, G. (2004). Assessment of $\mathrm{CaCl}_{2}, \mathrm{NaNO}_{3}$ and $\mathrm{NH}_{4} \mathrm{NO}_{3}$ extraction procedures for the study of $\mathrm{Cd}, \mathrm{Cu}, \mathrm{Pb}$ and $\mathrm{Zn}$ extractability in contaminated soils. Analytica Chimica Acta, 504, 217-226.

Trierweiler, J. E., \& Lindsay, W. L. (1969). EDTA-ammonium carbonate soil test for zinc. Soil Science Society of America Proceedings, 39, 49-54.

Vukadinović, V. \& Vukadinović, V. (2011). Ishrana bilja. Osijek, Hrvatska, Poljoprivredni fakultet u Osijeku.

Wångstrand, H., Eriksson, J., \& Öborn, I. (2007). Cadmium concentration in winter wheat as affected by nitrogen fertilization. European Journal of Agronomy, 26, 209214.

Wu, Z., McGrouther, K., Chen, D., Wu, W., \& Wang, H. (2013). Subcellular distribution of metals within Brassica chinensis L. in response to elevated lead and chromium stress. Journal of Agricultural and Food Chemistry, 61(20), 4715-4722. 